Social \& Cultural Geography, 2013

Vol. 14, No. 2, 131-144, http://dx.doi.org/10.1080/14649365.2012.753468

\title{
Commentary
}

\section{Postcolonial migrations}

\section{Susan P. Mains ${ }^{1}$, Mary Gilmartin ${ }^{2}$, Declan Cullen ${ }^{3}$, Robina Mohammad ${ }^{4}$,} Divya P. Tolia-Kelly ${ }^{5}$, Parvati Raghuram ${ }^{6} \&$ Jamie Winders $^{3}$

${ }^{1}$ Department of Geography, School of the Environment, University of Dundee, Dundee DD1 4HN, Scotland, UK, s.p.mains@dundee.ac.uk; ${ }^{2}$ Department of Geography, National University of Ireland Maynooth, Co Kildare, Ireland, mary.gilmartin@nuim.ie; ${ }^{3}$ Department of Geography, Syracuse University, Syracuse, NY 13244-1020, USA, drcullen@maxwell.syr.edu, jwinders@maxwell.syr.edu; ${ }^{4}$ Institute of Asian Studies, Universiti Brunei Darussalam, Bandar Seri Begawan, Brunei Darussalam; ${ }^{5}$ Department of Geography, Durham University, South Road, DH1 3LE Durham, UK, divya.tolia-kelly@durham.ac.uk and ${ }^{6}$ Department of Geography, Open University, Milton Keynes MK7 6AA, UK, parvati.raghuram@open.ac.uk

In this commentary, we argue for the relevance and importance of postcolonial theory to the study of migration and mobility. Building on a panel discussion at the 2009 Annual Meeting of the Association of American Geographers, we highlight a number of different ways in which this could take place. We suggest three possible interventions: stretching the boundaries of the spaces of the postcolonial; interrogating the spatial connections that are forged between disparate places through migration; and challenging singular or hierarchical notions of identity and/or place. In these ways, we conclude that postcolonial theory can complicate and enhance our understanding of migration, and that attention to migration research could, in turn, facilitate a 'social turn' for postcolonial geographies.

Key words: migration, postcolonial theory, identity, place, power.

\section{Introduction}

There is an explicit link between colonialism and patterns of migration. The colonial era facilitated new movements of people around the world, such as slaves and indentured workers from the colonies as well as settlers, administrators and 'adventurers' from the colonial 'centre'. Later, the postcolonial era brought about movements of people from the formerly colonized peripheries to the colonial centre, particularly to the UK, France and the 


\section{Susan P. Mains et al.}

Netherlands (Castles and Miller 2009: 101). Postcolonialism, Hall (1996) argues, has destroyed the distance between the colonial powers and their extended territories. The social and cultural geographies of postcolonialism, and their concomitant populations, have become increasingly tangible in a myriad of spaces-hospitals, public transportation, parliament, universities, television broadcasts, city councils and small businesses, to name a few-leading to Bennett's (1966) deliberately provocative claim of shifting movements of people as 'Colonization in Reverse'. In the contemporary world, the bodies of these postcolonial migrants continue to provide a daily reminder of the spaces and practices of colonial pasts and the necessity for a critical understanding of the postcolonial present (and future).

To understand these multifaceted contemporary human geographies, it is critical to understand the ways in which migrant bodies have become nexus points for spatial practices across many scales, for example: exclusion from affordable housing in specific neighbourhoods; violent racist attacks against individuals; reification in mainstream media as entrepreneurial 'success stories'; exemplars for national development and cultural diversity political debates; and individual case studies and/or faceless statistics, behind ever tightening immigration controls. It is also important to note that these experiences of postcolonialism and the sites with which they are currently associated are not only recent phenomena, but emerge from a long-standing public imaginary in which migrants are often viewed as being out of place-and time (McEwan 2008; Nash 2002). The critical interweaving of postcolonial theory and migration studies offers, therefore, a unique opportunity to reflect and ground our under- standings of mobility in more complicated and (hopefully) sensitive ways.

Despite the material links between colonialism, postcolonialism and migration, social scientists in general have been slow to address this intersection. As Mcllwaine (2008: 1) notes, 'explicit postcolonial interpretations of mobility drawing on empirically grounded work still remain quite scarce in relation to migration in particular'. There are some exceptions. This includes work on postcolonial migrants to the former colonial power, for example on British Asians (Dwyer 2000), on Irish migration to Britain (Walter 2001), Caribbean migrants to and from Britain (Chamberlain 1997; Conway and Potter 2006; Phillips and Potter 2006; Western 1992) and Latin American migrants to Spain (Escandell and Tapias 2010). Lahiri's (2011) work on London Brahmos, drawing on interviews with migrants who move between London and Kolkata, is a recent example. Here, the emphasis is on personal experiences as mediated by broader structures of colonial rule and its aftermath. More tangentially, there are some efforts to consider the relationship between migration and development from a postcolonial perspective (see Asis, Piper and Raghuram 2010), or to consider the relationship between migration and belonging in a postcolonial setting (see Ho 2006). In an attempt to consider the relationship between postcolonial theory and migration, a recent issue of the Journal of Ethnic and Migration Studies (2010, Volume 36(8)) focuses primarily on a particular category of postcolonial migrant: the expatriate or the mobile professional. That collection of papers fits within the 'new mobilities paradigm', which tends to privilege particular, unencumbered forms of migration. It also draws, most explicitly, on the work of Edward Said, and uses his idea of 'imagined geographies' to discuss the ways in 
which these expatriates understand the relationship between place and identity. Two approaches to the postcolonial are apparent in this diverse body of work. The first takes the postcolonial as a spatial and temporal stage on which migration is acted out. The second treats the postcolonial as an optic or lens through which to understand the cultural politics of the present (Fechter and Walsh 2010: 1202). Although both hint at the possibilities of a postcolonial understanding of migration, these possibilities are limited to either a material setting or a discursive methodology. As a consequence, the potential for postcolonial theory to fundamentally change how we understand migration is underexplored within geography and within the social sciences more generally.

The aim of this intervention is to illuminate this potential by pointing to the myriad ways in which postcolonial theory could inform the study of migration. It emerges from a panel discussion at the 2009 Annual Meeting of the Association of American Geographers in Las Vegas, where we discussed postcolonial migrations among the panel and with the audience. All the panel members research migration and are informed by postcolonial theory, and many also spoke from personal experiences of living, often as migrants, in places directly or indirectly shaped by colonialism. In these ways, the panel discussion melded together postcolonial theories and subjectivities. Following the panel discussion, all the participants agreed to write a short commentary that highlighted their perspectives on the intersections between postcolonialism and migration. In writing these commentaries, participants thus had the opportunity to reflect on their own contributions to the panel as well as on the discussion that followed. Though not directly reproduced as a dialogue, the commentaries that follow are influenced by the panel discussion, as well as by the participants' own experiences and perspectives on the postcolonial theory-migration intersection. The form and focus for the commentary was deliberately left open, in the hope of capturing and reflecting the wide range of possibilities for a productive intersection that emerged from the panel discussion.

The intervention opens with Raghuram's observations on how postcolonial theory fundamentally challenges the 'here' and 'there' of migration studies. As Raghuram notes, migration literature often takes these spatial concepts for granted: it is the movement between 'here' and 'there', rather than their mutual constitution, which most interests scholars of migration. Postcolonial theory messes up this neatly bounded relationship, but also points to the political possibility of recognizing a shared postcolonial terrain. Raghuram highlights a call to pluralize Asia: this is taken up by Mohammad, who highlights the ways in which the politics of the postcolonial period in Pakistan finds expression in the politicization of the Kashmiri diaspora, intimately involved in a nationalist project 'there' and 'here'. Both Mohammad and Cullen, whose work focuses on the Canadian province of Newfoundland, challenge our understanding of the spaces of postcolonialism. Cullen suggests that Newfoundland may be understood, although problematically, as a postcolonial space, and that migration-a fact of life for the provinceprovides a useful route to that understanding. In her contribution, Tolia-Kelly highlights the recurring but also frequently, uncritical use of 'diaspora' and 'cosmopolitanism' in migration research. She illustrates the potentially negative political implications of common approaches within human geography and urges scholars to engage with the embodied and contested terrains negotiated by migrants in a variety of 
complicated contexts. Finally, a cautionary note is sounded by Winders, as she writes about the challenges of using postcolonial theory to interrogate race and migration, both in her research and in the classroom. Winders suggests that postcolonial theory may be less effective in thinking about race, despite the obvious intersections between migration and the maintenance of racial hierarchies. The conclusion, by Mains and Gilmartin, reflects on the five contributions and on their call to reconsider the relationship between postcolonial theory and migration studies, within the broader context of social and cultural geography.

\section{Some thoughts emanating from a postcolonial analysis of migration}

For some time, the primary spatial narrative constructed in most migration literature has been the movement from 'there' to 'here' or from 'here' to 'there'. Most of the focus has been on movement across distance and the difference this has made to the places which people leave behind or come to. And because migration is an emotive public issue that is tied closely to politics and policy, the primary temporal register in which migration has been discussed is that of the immediate future.

However, the discursive limits of this way of thinking space-time have been fruitfully challenged by postcolonial theorists. Postcolonial theory has had an impact on the analytical landscape of migration in two ways. First, it has extended the temporality of the discussion by recognizing the extent to which today's migrations draw on colonial histories. Second, it has highlighted some ways in which distant places have refigured the near because 'here' has been formed and performed only through long interactions with 'there'. The 'here' and the 'there' are, therefore, already muddied. Migration is not only made multi-directional but stories of origin and destination also lose conviction. Such an analysis takes us further than the simultaneity of relations envisaged by migration theorists adopting the lens of transnationalism.

This multiplicity of movements and of complex belongings gains analytical recognition in stories of multisitedness and hybridity. However, these are increasingly being evoked in a landscape where singular belonging is also being emphasized. People are increasingly required to choose between here and there. The politics of belonging, which occupies centre stage in the troubled territories of nationalism and citizenship, has also become increasingly territorialized, securitized and penalized in receiving contexts. In the polarized discussions of belonging diasporics are continuously being asked to display how and in what ways 'you are one of us, not one of them'. Multiple identifications and contested affiliation are to be muffled; congealed into a publicly expressed singular narrative of belonging (Raghuram and Sahoo 2008).

How do we face up to the analytical challenges that these contradictory tendencies pose? This is a question that Spivak (2008) poses repeatedly in her work on Armenian postcoloniality where she argues that the Asia that is sought and described is often monochromatic and reflects back on the identities and regionalisms of those who aim to define and describe Asia. Moreover, she identifies this search for regionalism as a classed position and, therefore, warns us against the ossifying certainties of regionalism. She argues that pluralizing Asia is a step towards imagining a just world.

This also takes us some way towards theorizing postcolonial migration-not merely through the lens of the Asians who live around the globe because of the history of colonialism, but also because Asia is claimed in the 
memories and practices of those who have inhabited its land precisely as actors in that colonial history. In the context of Asia, it requires us to recognize the bits of Asia that reside in the Surrey Downs (Kothari 2006), in the Netherlands (Stoler and Strassler 2000) and in Pakistan (Cook 2007) because of the histories of colonial officers and development workers. The memories of those who travelled to Asia, made their careers there, brought up children in the colonies and learnt their trade of how to be 'Asianists'-these are the mobility stories garnered in narrating lives and narrating Asia around the globe. They exemplify how people in many parts of the world inhabit a shared postcolonial terrain.

\section{The partition of India, migration and internal colonialism}

Tan and Kudaisya (2000: 8) point out that the partition of India produced '...18 million [refugees who] struggled to resettle themselves and the energies of at least two generations were expended in rebuilding lives shattered by the violent uprooting caused by the partition'. Displacement and ongoing territorial conflicts are the legacy of this fracture. Indians often point to the costs of partition, in contrast to popular and political perception among Pakistanis that it was a major achievement. Yet not all subcontinental Muslims were in favour of it: '...Pashtuns for example, were late and reluctant in embracing the Muslim separatism of the All-India Muslim league's campaign for Pakistan' (Haqqani 2005: 560). Azad (free) Kashmiris have a particularly contentious relationship with the project that is Pakistan. In Britain, the largest group of 'Pakistanis' is made up of Kashmiris from the Mirpur district of Azad Kashmir.
Azad Kashmir is an area annexed by Pakistan to which India also lays claim. In recent years Azad Kashmiris themselves have become acutely aware of regional inequality and internal colonialism. Out-migration from the region began at the start of the twentieth century in response to limited economic opportunities in the area. It was given a further impetus with the Mangla Hydel project, built in 1967 with funding from the World Bank. The project involved damming the waters of the Jhelum and Poonch rivers as a protection against flooding, as a source of hydroelectric power as well as a water storage reservoir for the entire canal irrigation system of West Punjab and thus the project was crucial to the economy of Pakistan as a whole. The damming of the rivers was to have severe environmental and economic costs to the area as it submerged under water some of the most fertile land in the region and split the district into two, making flows between Dadial and Mirpur treacherous as well as costly in terms of money and time. Intercontinental commuters struggled to travel within the region. Returning with electrical goods they quickly became only too aware of how ' $[t]$ he benefits of Mangla's [cheap] electricity were felt in Lahore and Karachi, long before power lines began to be installed in rural Mirpur' (Ballard 1991: 517). These tensions fuelled a disillusionment with Pakistan, promoting anti-Pakistan sentiments that culminated in the raising of the Indian flags as a mark of protest and the resurrection of Kashmiriyat (Kashmiri nationalism) that was once strongest in the Kashmiri Valley (now on the Indian side). As Ali (2003: 476) notes: 'since the mid-1980s ... a Kashmiri nationalist discourse has become hegemonic, replacing narratives of traditional affiliations. This has coincided with the rise of diasporic organizations operating outside the India-Pakistan duopoly over Kashmir'. 
It is thus perhaps more accurate to state that it is because of the diaspora that Kashmiriyat and the call for independence has grown. The Jammu Kashmir Liberation Front was founded in Birmingham in 1977 and more recently, in 1999, the Kashmir National Identity Campaign was established with a view to ideologically disconnecting Kashmir from Pakistan and establishing Kashmiriyat as a separate identity in its own right.

The partition was an act to provide political self-determination for a minority, yet what has become clear is that this is a highly diverse and divided minority. These divisions structure and underpin regional inequality between the regions and centre, circumscribing relations between India and Pakistan over Kashmir, and between them and their diasporas around the globe. To focus on a postcolonial relationship between the colonizers (Britain) and a colonized (India) serves to occlude intrastate inequalities and promote the migration of particular groups from the periphery to the centre.

\section{Newfoundland}

Within both a Canadian and a wider transatlantic context, the eastern Canadian Province of Newfoundland is spatially and symbolically marginal. In reality, however, Newfoundland has been central, not just to the people who live there, but to those wider transatlantic networks of which it is part. In seeking to understand the 'place' of Newfoundland from its origins as a 'dying colonial regime' (Wright 2001) to its integration into the Canadian federal state, my research employs postcolonial theory, most often related to the global 'South', to generate insights into the complexity of Newfoundland's contemporary situation in the global
'North'. Part of the aim of this project is to test the geographical and epistemological limits of postcolonial theory in a North American context. Postcolonial theory has often been criticized for its pretensions to universal application. Such a claim is serious given the central importance within postcolonial studies of challenging the pretensions and colonial complicity of claims to universal knowledge (Blunt 2005; Mignolo 2000, 2005; Robinson 2003).

A postcolonial framing of Newfoundland is not a straightforward undertaking. The Manichean nature of the colonial encounter, embodied in the native-colonizer binary, has been vital to theorizing the cultural impacts of colonialism (Jan Mohammed 1985) and has been politically powerful (Fanon 1990). The initial destruction of the Beothuk population left Newfoundland without an easily identifiable colonial other; in some respects Newfoundlanders themselves became othered within the British Empire and subsequently as a Canadian province. Within postcolonial theory, the complexity, contingency and 'hybridity' of these relationships have become central to understanding the cultural identities (Bhabha 1994; Hall 1994). The strength of postcolonial geography lies in its aim to analyze 'the critical connections between past and present, metropolis and colony, colonizer and colonized, and chart the fractures, instabilities and contradictions of colonial rule' (Blunt 2005: 176). Within postcolonial contexts and theory, these critical connections between here and there, past and present, are often embodied in the figure of the migrant. Foregrounding the experience of migration can destabilize dominant narratives of spatial identity of Newfoundland situating it in political-economic and closely related imperial and colonial networks. 
Migration has been a constant fact of life in Newfoundland as its people have negotiated the rhythms of international capital and the sea. The origins of the colony lie in migratory fisheries. Furthermore, migration has enabled the survival of the former colony for over a century. By the late nineteenth century, the traditional economy had reached a limit to its extensive growth and 'further development was perceived as a function of the emergence of modern resource industries with emigration acting as a mechanism to balance a labour force growing faster than employment opportunities' (Alexander 1980: 25). Despite over a century of persistent emigration for many migrants, pre-Confederation life is thought of in the same nostalgic vein as a European homeland for other New World immigrants'a homeland that sometimes was left because of economic and political turmoil' (Pocius 2000: 19). A postcolonial approach to migration from, and indeed return migration to, Newfoundland blurs the contours of a seemingly fixed identity while also challenging the spaces, both theoretical and literal, where 'New-found-land' (Sparke 1995) is produced and reproduced.

\section{Re-thinking postcolonial cosmopolitanisms}

The categories of 'postcolonial' and 'migration' are at the heart of geopolitical struggles in contemporary society because colonial accounts of race are often presented through them and used to figure spatial routes of movement. Recent postcolonial theorizations effectively disrupt discourses of race, postcolonialism, diaspora and cosmopolitanism through a notion of transcultural affects (Conradson and Mckay 2007), 'categories' (Jones 2009) and narrative (Tolia-Kelly 2011).
Diaspora as a conceptual framework is a deeply geopolitical, temporal and spatial mode of being, living and identification for many writers, but has been deemed problematic. There is a bounded nature at the heart of accounts of ethnic diasporas which requires a productive critique. In more recent research, it has been critical to move towards thinking mobilities through millennia to disrupt bounded accounts of national identity and migrant bodies. We are all at once diasporic and cosmopolitan (for recent accounts see Clark 2002; Turner 2002), if we consider longitudinal time, or at least the last two millennia (Nesbit and Tolia-Kelly 2009; Witcher, Tolia-Kelly and Hingley 2010).

Cosmopolitanism is 'an intellectual and aesthetic stance of openness towards divergent cultural experiences' (Hannerz 1990: 239). It is intended as an orientation towards acknowledging, in a positive way, the nature of exchanges and experiences across cultures, borders and societies. However, the lens of 'cosmopolitanism' is often a term that has a limited field of encounter (Beck 2002; Cheah and Robbins 1998). It evades, for example, postcolonial migration and the position of the marked body. The cosmopolitans we are drawn to in social science research are often globally migrant figures traversing in apparently evenly globalized communication, transport and cultural networks (Binnie and Skeggs 2004). Formulations of a 'cosmopolitan identity' remain Eurocentric and the historical trajectory of the cosmopolitan imagination and vernacular expressions in everyday local life and culture have, on the whole, been neglected (Nava 2002).

'Transnationalism' (see, for example, Crang, Dwyer and Jackson 2003) has also been a new way of considering mobility, race and networks in a culturally fluid and globalizing world but while retaining a notion 
of 'difference' that is situated within a western lens of often ossified characterizations of 'national' or 'community' practices (see Modood 1990). Thinking 'difference' through an account of cosmopolitanism that embraces transnational peoples (Turner 2002) challenges the stereotypes of diasporic communities as being culturally homogenous citizens of post-imperial political rule. Critical challenges to the usual notions of diaspora are at the heart of Young's (2007) account of the English as being diasporic. His notion of the 'diasporic English' is at heart an export of a sensibility and set of values that continue in global circulation as part of postcolonial cultural narratives. Englishness is only meaningful through circulation.

Instead of thinking of movement as arrows across maps, lines are deemed intellectually, historically and archaeologically more appropriate. Lines do not determine boundedness of the communities from which folk came; or those to which folk are moving. Instead lines acknowledge that circulation, movement and cultural transfer have been integral to human populations, their cultures and society. Diffusion, synthesis and osmosis are preferable metaphors. Arrows are intellectual violences, just as in postcolonial literatures violences are marked in the textual encounter.

There is a doubleness here; text removes embodied accounts and yet the text is structurally situated as disembodying and colonizing. In the process of migration, the tragedy is that the textual record, genealogy and heritage literature is misplaced. Text, identity and histories are ephemeral and migrants' bodies often do not matter (Amoore and Hall 2009). This is why it is even more important to engage with migration research without a singular focus on 'identity' where the histories of violences are edited out and contemporary oppression diluted. Exchanges are politically and ethically necessary between the two realms of postcolonial theory and bodies of work on migration. For postcolonial migrants, abjection is in the fabric of everyday life; including the risk of elimination of body, of experience, counter-oppression, rupture, mimesis, self-hate and denials.

\section{Postcolonial migrations: postcolonialism migrates?}

The topics of race and migration-how racial categories and practices are produced and contested, and sustained across spaces and scales and through geographies of migration and mobility-are central to my research on historical and contemporary migration and mobility across North America. Postcolonial theory weaves through some of this work. McClintock (1995), Fanon (1967) and Said (1978), for example, inform my analysis of intra-national dynamics of race, nation, and nature in the post-bellum US South (Winders 2005a) and of whiteness, transnationalism and beauty in contemporary Mexico (Winders, Jones and Higgins 2005). In my research on Latino migration and racial politics in the contemporary US South (Winders 2005b, 2007, 2008a, 2008b), postcolonial attention to power and difference, voice and representation, influences how and why I conduct this work; but I struggle to articulate how immigrant experiences with historically deep racial formations in southern US locales relate to conceptual and empirical work in more 'postcolonial' locales.

Postcolonial theory is more prominent in my classroom, where teaching human geography is teaching postcolonial theory. Postcolonial theorists show up in introductory human geography, where they infuse how I teach coreperiphery linkages and students write about 
the 'colonial present' (Ashutosh and Winders 2009; Gregory 2004). Postcolonial theory figures in my seminars, where students read Bhabha, examine transnational flows and reflect on the experiences and contradictions of being 'in-between' for writers from Fanon to Anzaldúa. The saliency, and ease, of applying postcolonial theory, however, is as uneven across my courses as it is across my research. Here, I reflect on this unevenness and the place of race in teaching and using postcolonial theory vis-à-vis migration.

In my undergraduate seminar on migration and mobility, students examine topics from transnationalism to borders, from immigration policy to immigrant experiences. In the process, they often latch onto Bhabha's hybridity and third space as salient, if complex, frameworks for thinking about migration (1994). Although students, like many of us, do not always understand the specifics of third space, it enables them to deconstruct migration's spatial and social binaries (here/there; immigrant/native; home/away) and imagine what it might mean to move 'beyond' the weight of colonialism by beginning 'somewhere else'.

Several undergraduates from this seminar also take my seminar on race and racism. In moving from one seminar to the other, they take Bhabha with them, attempting to use third space as a way out of fixed racial binaries. Even after reading about mixed-race identities and other potential challenges to rigid categories, however, students struggle to reconcile race as historically and geographically contingent and racism as seemingly transcendent. Accurately or not, they frequently see race, and especially racism, as 'fixing' more than 'thirding', as escapable through Fanon's revolution, not Bhabha's hybridity. A postcolonial ontology of hybridity and third space, then, does not always offer students the same political possibility in the context of race that it does in the context of migration. This limit, of course, partially reflects the theoretical edge of what undergraduates can grasp and what I present to them. It is telling, however, that students, like me, stumble in moving postcolonial theory from migration/mobility to race/racism, particularly in a US context. This imperfect translation of postcolonial theory from migration to race raises thorny questions about its political possibility for migration and race.

\section{Conclusion}

There is, as Tolia-Kelly argues, a political and ethical necessity to bring postcolonial theory and migration research into dialogue. The five contributions highlight a number of ways in which this might happen: by stretching the boundaries of the spaces of the postcolonial; by interrogating the spatial connections that are forged between disparate places through migration and by challenging singular or hierarchical notions of identity and/or place. Yet this is not an unproblematic dialogue, as the contributions also highlight. The narrow definition of the postcolonial within geography leads to struggles over what and where, precisely, the postcolonial is located. Winders highlights this tension, when she writes of particular places being more or less postcolonial. Similarly, the narrow understanding and application of postcolonial theory within geography means that, too often, postcolonial theory is used as a discursive methodology, rather than as a challenge to dominant epistemologies within the discipline. Geographers have too often focused on the how, rather than the more challenging question of 'who, when, why is constructing knowledges' 
(Mignolo 2009: 160). Within geography, two recent discussions of migration make epistemological or ontological, rather than methodological, use of postcolonial theory. Yeoh (2003: 375), in her nuanced discussion of the postcolonial geographies of place and migration, writes of the multifarious and ramifying connections between colonial and postcolonial encounters. Meanwhile, Raghuram uses the example of the migration of medical doctors to illustrate a broader point about what she calls 'postcolonial responsibility' (Raghuram 2009: 31). As she argues, a postcolonial responsibility needs to 'take cognizance of the interconnectedness between different spaces', over a time period that stretches across colonialism and its aftermath (Raghuram 2009: 31). In each of these discussions, grounded in the postcolonial landscapes of Japan, Singapore and the UK's National Health Service, postcolonial theory offers a way to understand migration that stretches beyond economic imperatives, narrow time-frames and individualized experiences.

Developing and critiquing geographic conceptualizations of responsibility via 'postcolonial interventions,' Noxolo, Raghuram and Madge (2012: 424) challenge the often unspoken uneven power relations that continue to frame research. The authors demonstrate that resisting questioning or embracing enigmatic and risky relationships may be a useful way of rethinking postcolonial geographies while noting that 'Responsible, caring action therefore involves an openness and vulnerability to that which most resists European thought: those aspects of the "other" that are not shared and are nor comfortable.' The authors demonstrate that academics' desires to forge 'connections' and find 'answers' may fail 'to unsettle these interactions and connections' in fundamental ways (Noxolo, Raghuram and Madge 2012: 425), which also poses important challenges for this dialogue-and our future conversations-about the ways in which (dis)connections and the experiences of migration may be engaged through multifaceted processes. In short, postcolonial theory directs us-in compelling ways-to question how we construct knowledge about migration, and whose interests this serves. The importance of this reconceptualization of binary identities towards an understanding of place that engages, and re-situates collaborative postcolonial practices, is noted by McKittrick (2011) in her discussion of a black sense of place, asking:

how we can and will re-evaluate the commonsense workings of violence and death and re-think analyses of injustice that re-isolate the dispossessed. Instead of pointing to those 'without' and citing injustice, we might imagine how we are intimately tied to broader conceptions of human and planetary life and which demonstrate our common and difficult histories of encounter (2011: 960).

McKittrick's challenge to geographers is an important one for working through our understandings of postcolonial migrations, and for interrogating sites and narratives of mobility and migration not only as generalized struggles over power, but also as ongoing negotiations and decision-making practices, which have people at their centre.

Migration, and our knowledge of migration, is profoundly shaped by colonialism and its aftermath. Taking seriously the topic of postcolonial migrations means that we question the basis of our understanding of migration. This applies as much to the foundational text of migration studies within geography, Ravenstein's 'Laws of Migration' 
(1885)—which is clearly a product of the British colonial era-as it does to migration statistics from the contemporary era. It refers to the methodologies we use to gather information about migration, from statesponsored large-scale data collection to qualitative methods that frame the 'lived experience' of the migrant through the gaze of the 'native'. And it means that we must continue to interrogate what Mignolo describes as the 'colonial matrix of power' (2009: 178): the racialized classifications of people and places that persist in contemporary geography. Through the contributions in this intervention, we have seen ways in which this might happen, from the identification of alternative postcolonial linkages and shared postcolonial terrain to the recognition of the abjection of postcolonial migration. We have also seen that this process is far from straightforward: it raises difficult, and often unanswerable questions, and it unsettles geographic and epistemological certainties. Yet, it is necessary, if we are to challenge the disciplinary ruts into which both postcolonial theory and migration research have settled, and which 'necessitate interrogating the legacy of its post-colonial present' (Peake 2011: 768).

To begin-and conclude-this critical commentary, we aim to briefly outline a vision of the possible journeys and forms of engagement that we believe could build on the existing work of Social \& Cultural Geography. There is no single narrative that provides a neat pathway through the varied contexts and topics raised above, however, we do believe that the broader themes of identity, power and representation can be more closely explored and scrutinized in relation to how postcolonialism and migration have been situated within social and cultural geography. Within geography more generally, there has been a tendency to situate migration research within the context of social geography-perhaps reflecting a broader heritage of population, development, welfare and mobility studies. In contrast, postcolonial critiques of inequality, place and spatial practices have been more centrally placed within the rubric of cultural geography. Under closer scrutiny, however, these apparently parallel journeys are not so clearly distinct. As can be seen from the discussion above-and through a closer examination of the intersections between policies, spatial practices and representations of mobilities-postcolonial migrations doand can-provide significant opportunities to interweave social and cultural geography concerns in tandem with methodologically diverse approaches, and in a more sustained manner.

As part of this journal's 2011 forum explicitly exploring social geography (Del Casino 2011; Smith, Brown and Bissell 2011), Hopkins (2011: 537) asks: 'Perhaps social geographers could be strengthened further through a social turn?' Building on this we could also ask: could postcolonial geographies take a social turn as part of a dialogue with migration research? In addition, we believe that there is an exciting opportunity for scholars to develop and broaden this discussion, to more explicitly engage with work currently categorized as 'population geography' and, by fostering this discussion, to continue to mobilize new perspectives on postcolonial migrations that enrich and complicate our understandings of people, knowledge and place.

\section{References}

Alexander, D. (1980) Newfoundland's traditional economy and development to 1934, in Hiller, J. and Neary, P. (eds) Newfoundland in the Nineteenth and Twentieth 
Centuries: Essays in Interpretation. Toronto: University of Toronto Press, pp. 17-39.

Ali, N. (2003) Diaspora and nation: displacement and the politics of Kashmiri identity in Britain, Contemporary South Asia 12(4): 471-480.

Amoore, L. and Hall, A. (2009) Digitised dissection and the body at the border, Environment and Planning D: Society and Space 27: 444-464.

Ashutosh, I. and Winders, J. (2009) Teaching orientalism in introductory human geography, Professional Geographer 61(4): 547-560.

Asis, M.M., Piper, N. and Raghuram, P. (2010) International migration and development in Asia: exploring knowledge frameworks, International Migration 48: 76-106.

Ballard, R. (1991) The Kashmir crisis: a view from Mirpur, Economic and Political Weekly 26(9-10): 513-517.

Beck, U. (2002) The cosmopolitan society and its enemies, Theory, Culture and Society 19(1-2): 17-44.

Bennett, L. (1966) Jamaica Labrish. Kingston: Sangster's. Bhabha, H. (1994) The Location of Culture. London \& New York: Routledge.

Binnie, J. and Skeggs, B. (2004) Cosmopolitan knowledge and the production and consumption of sexualised space: Manchester's gay village, Sociological Review 52: $39-61$.

Blunt, A. (2005) Colonialism/postcolonialism, in Atkinson, D., Jackson, P., Sibley, D. and Washbourne, N. (eds) Cultural Geography: A Critical Dictionary of Key Concepts. London: I.B. Tauris, pp. 175-181.

Castles, S. and Miller, M.J. (2009) The Age of Migration: International Population Movements in the Modern World, 4th ed. Basingstoke: Palgrave Macmillan.

Chamberlain, M. (1997) Narratives of Exile and Return. London: Macmillan. University of Warwick Caribbean Studies Series.

Cheah, P. and Robbins, B. (1998) Cosmopolitics: Thinking and Feeling Beyond the Nation. Minneapolis, MN: University of Minnesota Press.

Clarke, N. (2002) The Demon Seed, Theory Culture and Society 19(1-2): 101-125.

Conradson, D. and Mckay, D. (2007) Translocal subjectivities: mobility, connection and emotion, Mobilities 2(2): 167-174.

Conway, R.B. and Potter, J. (2006) Citizens by Descent: Bajan-Brit Young Return Migrants. Aldershot and Burlington, VT: Ashgate.

Cook, N. (2007) Gendered globe-trotting: mapping development travels in Northern Pakistan, Paper presented at the Annual Association of American Geographers, April 17-21, San Francisco.

Crang, P., Dwyer, C. and Jackson, P. (2003) Transnationalism and the spaces of commodity cultures, Progress in Human Geography 27(4): 438-456.

Del Casino, V. (2011) US Social geography, alive and well?, Social \& Cultural Geography 12(6): 538-543.

Dwyer, C. (2000) Negotiating diasporic identities: Young British South Asian Muslim women, Women's Studies International Forum 23(4): 475-486.

Escandell, X. and Tapias, M. (2010) Transnational lives, travelling emotions and idioms of distress among Bolivian migrants in Spain, Journal of Ethnic and Migration Studies 36(3): 407-423.

Fanon, F. (1967) [1952]. Black Skin, White Masks. trans. by Charles Lam Markmann. New York: Grove Press, Inc.

Fanon, F. (1990) The Wretched of the Earth. London: Penguin Books.

Fechter, A-M. and Walsh, K. (2010) Examining 'expatriate' continuities: postcolonial approaches to mobile professionals, Journal of Ethnic and Migration Studies 36(8): 1197-1210.

Gregory, D. (2004) The Colonial Present: Afghanistan, Palestine, Iraq. Malden and Oxford: Blackwell.

Hall, S. (1994) Cultural identity and diaspora, in Williams, P. and Chrisman, L. (eds) Colonial Discourse and Post-Colonial Theory: A Reader. New York: Columbia University Press, pp. 222-237.

Hall, S. (1996) When was 'the post-colonial'? Thinking at the limit, in Chambers, I. and Curti, L. (eds) The Postcolonial Question: Common Skies, Divided Horizons. London: Routledge, pp. 242-260.

Hannerz, U. (1990) Cosmopolitans and locals in world culture, Theory Culture and Society 7: 237-251.

Haqqani, H. (2005) Pakistan Between Mosque and Military. Washington, DC: Carnegie Endowment for International Peace.

Ho, E.L. (2006) Negotiating belonging and perceptions of citizenship in a transnational world: Singapore, a cosmopolis?, Social \& Cultural Geography 7(3): 385-402.

Hopkins, P. (2011) Multiple, marginalized, passé or politically engaged? Some reflections on the current place of social geographies, Social \& Cultural Geography 12(6): 533-538.

Jan Mohamed, A. (1985) The economy of Manichean allegory: the function of racial difference in colonialist literature, Critical Inquiry 12(1): 59-87. 
Jones, R. (2009) Categories, borders and boundaries, Progress in Human Geography 33(2): 175-189.

Kothari, U. (2006) Spatial practices and imaginaries: experiences of colonial officers and development professionals, Singapore Journal of Tropical Geography 27: $235-253$.

Lahiri, S. (2011) Remembering the city: translocality and the senses, Social \& Cultural Geography 12(8): 855-869.

McClintock, A. (1995) Imperial Leather: Race, Gender and Sexuality in the Colonial Contest. London: Routledge.

McEwan, C. (2008) Postcolonialism and Development. London: Routledge.

McIlwaine, C. (2008) The postcolonial practices of international migration: Latin American migration to London, Working paper, http://www.geog.qmul.ac.uk/ docs/staff/6312.pdf (accessed 16 August 2012).

McKittrick, K. (2011) On plantations, prisons, and a black sense of place, Social \& Cultural Geography 12(8): 947-963.

Mignolo, W.D. (2000) Local Histories/Global Designs: Coloniality, Subaltern Knowledges, and Border Thinking. Princeton, NJ: Princeton University Press.

Mignolo, W.D. (2005) On subalterns and other agencies, Postcolonial Studies 8(4): 381-407.

Mignolo, W.D. (2009) Epistemic disobedience, independent thought and decolonial freedom, Theory, Culture o Society 26(7-8): 159-181.

Modood, T. (1990) Muslims, race and equality in Britain: some post-Rushdie affair reflections, Third Text 4(11): 127-134.

Nash, C. (2002) Cultural geography: postcolonial cultural geographies, Progress in Human Geography 26(2): 219-230.

Nava, M. (2002) Cosmopolitan modernity: everyday imaginaries and the register of difference, Theory Culture and Society 19(1-2): 81-99.

Nesbitt, C. and Tolia-Kelly, D.P. (2009) Hadrian's Wall: embodied archaeologies of a linear monument, Journal of Social Archaeology 9: 368-390.

Noxolo, P., Raghuram, P. and Madge, C. (2012) Unsettling responsibility: postcolonial interventions, Transactions of the Institute of British Geographers 37(3): 418-429.

Peake, L. (2011) In, out and unspeakably about: taking social geography beyond an Anglo-American positionality, Social \& Cultural Geography 12(7): 757-773.

Phillips, R.B. and Potter, J. (2006) Both black and symbolically white: the 'Bajan-Brit' return migrant as post-colonial hybrid, Ethnic and Racial Studies 29(5): 901-927.

Pocius, G. (2000) A Place to Belong: Community, Order and Everyday Space in Calvert, Newfoundland. Montreal: McGill-Queen's University Press.

Raghuram, P. (2009) Caring about 'brain drain' migration in a postcolonial world, Geoforum 40: 25-33.

Raghuram, P. and Sahoo, A.K. (2008) Thinking 'Indian Diaspora' for our times, in Raghuram, P., Sahoo, A.K., Maharaj, B. and Sangha, D. (eds) Tracing an Indian Diaspora: Contexts, Memories, Representations. Los Angeles \& London: Sage, pp. 1-20.

Ravenstein, E.J. (1885) The laws of migration, Journal of the Statistical Society of London 48(2): 169-235.

Robinson, J. (2003) Postcolonialising geography: tactics and pitfalls, Singapore Journal of Tropical Geographies 24: 273-289.

Said, E.W. (1978) Orientalism. New York: Vintage Books. Smith, D.P., Browne, K. and Bissell, D. (2011) Reinvigorating social geographies? A 'social return' for a changing social world: (re)opening a debate, Social \& Cultural Geography 12(6): 517-528.

Sparke, M. (1995) Between demythologizing and deconstructing the map: Shawnadithit's New-found-land and the alienation of Canada, Cartographica 32(1): 1-21.

Spivak, G.C. (2008) Other Asias. Victoria: Blackwell.

Stoler, A. and Strassler, K. (2000) Castings for the colonial: memory work in new order java, Comparative Studies in Society and History 42(1): 4-48.

Tan, T.Y. and Kudaisya, G. (2000) The Aftermath of Partition in South Asia. London: Routledge.

Tolia-Kelly, D.P. (2011) Narrating the postcolonial landscape: archaeologies of race at Hadrian's Wall, Transactions of the Institute of British Geographers 36(1): $71-88$.

Turner, B. (2002) Cosmopolitan virtue, Theory Culture and Society 19(1-2): 45-63.

Walter, B. (2001) Outsiders Inside: Whiteness, Place and Irish Women. London: Routledge.

Western, J. (1992) A Passage to England: Barbadian Londoners Speak of Home. Minneapolis, MN: University of Minnesota Press.

Winders, J. (2005a) Changing politics of race and region: Latino Migration to the U.S. South, Progress in Human Geography 29(6): 683-699.

Winders, J. (2005b) Imperfectly imperial: Northern Travel Writers in the Postbellum U.S, South, 1865-1880, Annals of the Association of American Geographers 95(2): 391-410. 


\section{Susan P. Mains et al.}

Winders, J. (2007) Bringing back the (B)order: post-9/11 politics of immigration, borders, and belonging in the contemporary U.S. South, Antipode 39(5): 920-942.

Winders, J. (2008a) An 'incomplete' picture? Race, Latino Migration, and Urban Politics in Nashville, Tennessee, Urban Geography 29(3): 246-263.

Winders, J. (2008b) Nashville's New Sonido: Latino migration and the changing politics of race, in Massey, D. (ed.) New Faces in New Places: The Changing Geography of American Immigration. New York: Russell Sage Foundation, pp. 249-273.

Winders, J., Jones, III, J.P. and Higgins, M. (2005) Making Güeras: selling white identities on late-night Mexican television, Gender, Place, and Culture 12(1): 71-93.
Witcher, R., Tolia-Kelly, D.P. and Hingley, R. (2010) Archaeologies of landscape: excavating the material geographies of Hadrian's Wall, Journal of Material Culture 15(1): 105-128.

Wright, M. (2001) A Fishery for Modern Times: The State and the Industrialization of the Newfoundland Fishery, 1934-1968. Oxford: Oxford University Press.

Yeoh, B. (2003) Postcolonial geographies of place and migration, in Anderson, K., Domosh, M., Pile, S. and Thrift, N. (eds) Handbook of Cultural Geography. London: Sage, pp. 369-380.

Young, R.J.C. (2007) The Idea of English Ethnicity. London: Blackwell. 